Article

\title{
Isoprene Oxidation by the Gram-Negative Model bacterium Variovorax sp. WS11
}

\author{
Robin A. Dawson ${ }^{1}$, Nasmille L. Larke-Mejía ${ }^{1}$, Andrew T. Crombie ${ }^{2}$, \\ Muhammad Farhan U1 Haque ${ }^{3}$ and J. Colin Murrell ${ }^{1, *}$ \\ 1 School of Environmental Sciences, Norwich Research Park, University of East Anglia, Norwich NR4 7TJ, UK; \\ R.Dawson@uea.ac.uk (R.A.D.); n.mejia@uea.ac.uk (N.L.L.-M.) \\ 2 School of Biological Sciences, Norwich Research Park, University of East Anglia, Norwich NR4 7TJ, UK; \\ A.Crombie@uea.ac.uk \\ 3 School of Biological Sciences, University of the Punjab, Quaid-i-Azam Campus, Lahore 54000, Pakistan; \\ mfarhan.sbs@pu.edu.pk \\ * Correspondence: j.c.murrell@uea.ac.uk; Tel.: +44-1603-592-959
}

Received: 11 February 2020; Accepted: 28 February 2020; Published: 29 February 2020

\begin{abstract}
Plant-produced isoprene (2-methyl-1,3-butadiene) represents a significant portion of global volatile organic compound production, equaled only by methane. A metabolic pathway for the degradation of isoprene was first described for the Gram-positive bacterium Rhodococcus sp. AD45, and an alternative model organism has yet to be characterised. Here, we report the characterisation of a novel Gram-negative isoprene-degrading bacterium, Variovorax sp. WS11. Isoprene metabolism in this bacterium involves a plasmid-encoded iso metabolic gene cluster which differs from that found in Rhodococcus sp. AD45 in terms of organisation and regulation. Expression of iso metabolic genes is significantly upregulated by both isoprene and epoxyisoprene. The enzyme responsible for the initial oxidation of isoprene, isoprene monooxygenase, oxidises a wide range of alkene substrates in a manner which is strongly influenced by the presence of alkyl side-chains and differs from other well-characterised soluble diiron monooxygenases according to its response to alkyne inhibitors. This study presents Variovorax sp. WS11 as both a comparative and contrasting model organism for the study of isoprene metabolism in bacteria, aiding our understanding of the conservation of this biochemical pathway across diverse ecological niches.
\end{abstract}

Keywords: isoprene; microbiology; monooxygenase; mutagenesis; isoprene-fed fermentor

\section{Introduction}

Many volatile organic compounds (VOCs) influence atmospheric chemistry, typically as a result of their breakdown via physical and chemical processes. Isoprene accounts for one-third of biogenic VOCs emitted to the atmosphere, with production by terrestrial plants accounting for approximately $500 \mathrm{Tg}$

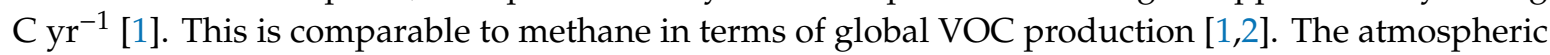
half-life of isoprene is short due to the reactivity of its two alkene groups [2]. The presence of the $\mathrm{C}=\mathrm{C}$ double bonds makes isoprene prone to nucleophilic attack by hydroxyl radicals, and thus isoprene is an indirect contributor to global warming due to competition for hydroxyl radicals responsible for the removal of atmospheric methane [2]. The products of isoprene oxidation form secondary organic aerosols that can act as cloud condensation nuclei, causing the shielding effects which contribute to global cooling [3,4]. Isoprene also influences levels of ozone. $\mathrm{NO}_{\mathrm{x}}$ levels associated with urban environments react with isoprene oxidation products, generating various compounds including $\mathrm{O}_{3}$ [2]. Conversely, ozone is depleted from low- $\mathrm{NO}_{x}$ areas due to the direct reaction of isoprene with $\mathrm{O}_{3}$ [5]. 
Isoprene synthase (IspS) is the key enzyme in biogenic isoprene production [6,7]. ispS is sporadically distributed in terrestrial plants, with varied roles being suggested for isoprene production including protection against heat and oxidative stress [8-11]. Despite the debate surrounding the biological role of isoprene, the significance of isoprene production in plants is clear when considering the metabolic costs. A single molecule of isoprene requires the input of 6 carbon atoms, 20 ATP and 14 NADPH [8] and thus, given that the production of isoprene typically uses $2 \%$ of fixed carbon [8], represents a significant investment by the tree. The roles of isoprene in abiotic stress responses in plants have been discussed by Vickers et al. $[9,10]$. Recent studies have demonstrated that isoprene influences gene expression in plants, as reviewed by Lantz et al. [12]. For example, Arabidopsis thaliana, a non-isoprene emitter, engineered to express ispS from Eucalyptus globulus, demonstrated regulation of isoprene emission and photosynthesis pathways which were comparable to the native emitter [11]. The protective role of isoprene against heat and light stress was also demonstrated when Arabidopsis thaliana was fumigated with isoprene [13]. The overlap of gene expression in the fumigation and transgenic expression models indicated a role of isoprene emission in the regulation of plant genes. Marine algae are another biogenic source of isoprene, with estimates ranging from 0.1 to $12 \mathrm{TgC} \mathrm{yr}^{-1}$

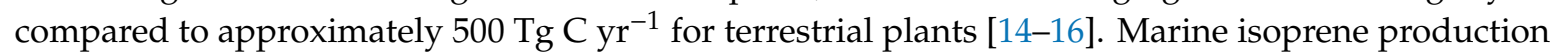
can support growth of a variety of isoprene-degrading bacteria [17].

Isoprene-degrading bacteria are present in different environments, with fresh water, marine, and soils representing sinks for isoprene, with initial estimates suggesting that $20.4 \mathrm{Tg} \mathrm{C} \mathrm{yr}^{-1}$ are consumed by soil $[18,19]$. Bacteria capable of growth on isoprene as the sole source of carbon and energy have been known for many years [20,21]. It was noted that two novel isoprene-degrading bacteria of the genera Alcaligenes and Rhodococcus were remarkably effective at biotransformations of trichloroethene and other halogenated hydrocarbons, although these organisms were not characterised in detail [21]. There is considerable conservation at the genetic level amongst isoprene degraders. All extant isoprene-degrading bacteria contain an isoprene degradation (iso) gene cluster, depicted in Figure 1 . iso $A-F$ encodes isoprene monooxygenase, a four-component soluble di-iron monooxygenase (SDIMO), which catalyses the epoxidation of isoprene to epoxyisoprene [22-24]. Isoprene monooxygenase (IsoMO) has been characterised in Rhodococcus sp. AD45, an actinobacterium isolated from freshwater sediment which has served as a model for isoprene metabolism research since the work of van Hylckama Vlieg et al. [22-24]. Epoxyisoprene is conjugated with glutathione by a glutathione $S$-transferase (IsoI), forming 1-hydroxy-2-glutathionyl-2-methyl-3-butene (HGMB), followed by two dehydrogenation steps catalysed by IsoH to form 2-glutathionyl-2-methyl-3-butenoate (GMBA) [22,23]. Further steps of isoprene degradation are still largely unknown, although it has been postulated that the glutathione moiety is removed and the product enters central metabolism through $\beta$-oxidation $[24,25]$.

Recent studies have begun to reveal the diversity of isoprene-degrading bacteria in the environment, with soils, leaves, and estuarine sediments being targeted by cultivation-independent stable isoprene probing (SIP) to identify the active isoprene-utilising communities. The alpha-oxygenase component of isoprene monooxygenase, isoA (see below), has been identified as an excellent target for molecular probes when investigating the molecular ecology of isoprene degraders [26,27]. Actinobacteria are among the most commonly identified isoprene degraders, and members of the $\alpha, \beta$, and $\gamma$-proteobacteria and the Bacteroidetes have also been identified [27-30]. Rhodococcus is often observed during studies of isoprene-degrading communities. Freshwater sediment enrichments contained approximately $50 \%$ relative abundance of $i s o A$ sequences related to Rhodococcus, while soil from beneath poplar, oil palm, and willow trees contained greater relative abundance of $i s o A$ relating to Variovorax spp., a member of the family Comamonadaceae (Betaproteobacteria) [26-28,30]. A recent study of willow soil reported that Comamonadaceae were enriched at $25 \mathrm{ppmv}$ isoprene, a lower concentration than has previously been used in enrichment of isoprene degraders [30]. Members of the Comamonadaceae have also been identified following isoprene enrichment in soils from willow trees (Salix spp.) and a tyre dump, and also from the phyllosphere of poplar trees using DNA-stable isotope probing (DNA-SIP) methods, indicating that members of this family may be significant in microbial cycling of isoprene [26-28,30]. 
Isoprene-degrading bacteria from the $\alpha$ - and $\gamma$-Proteobacteria and Firmicutes have recently been isolated from the leaves and soil samples from tropical trees [31], and bacteria capable of co-oxidation of isoprene have also been isolated from soils, although none of these isolates have been characterised in detail [32].

Variovorax spp. are noted for their metabolic versatility [33,34], mutualistic interactions with plants and bacteria [35-37], and their distribution in varied ecological niches [38]. Members of this genus are noted for their ability to grow in environments contaminated by a range of aliphatic, aromatic and halogenated hydrocarbons [39-41]. The metabolic capabilities of Variovorax have been reviewed by Satola et al. [42]. Working with a novel Variovorax isolate, sp. WS11, this study aimed to confirm its mechanism of isoprene metabolism. We conducted a physiological characterisation to determine the similarities and differences in isoprene metabolism between Rhodococcus sp. AD45 and our Gram-negative isolate Variovorax sp. WS11. This study describes the genome of Variovorax sp. WS11 and reports on its functional potential, particularly relating to the abundance of various putative oxygenase genes. We link isoprene metabolism in Variovorax sp. WS11 to a conserved metabolic gene cluster, demonstrate the oxidative range of the IsoMO, and identify key functional differences between IsoMO and a well-characterised SDIMO from a methane-oxidising bacterium. Variovorax sp. WS11 has provided insights into a conserved mechanism of isoprene degradation and aid our understanding of the role of bacteria in the isoprene biogeochemical cycle.

\section{Materials and Methods}

\subsection{Growth Conditions}

Variovorax sp. WS11 [28] was grown in minimal medium (herein Ewers medium) [43] buffered to pH 6.0 with phosphate and supplemented with $1 \mathrm{~mL} / \mathrm{L}$ vitamin solution [44]. Cultures were grown at $30{ }^{\circ} \mathrm{C}$ with shaking at $160 \mathrm{rpm}$. Unless stated otherwise, all cultures were grown in $120 \mathrm{~mL}$ vials sealed with butyl rubber stoppers. Typically, $1 \% v / v$ isoprene in the headspace of $120 \mathrm{~mL}$ vials was used. Headspace isoprene was measured according to Crombie et al. [45]. Sugars and carboxylic acids were used as growth substrates at $10 \mathrm{mM}$, and alkenes were used at $0.1 \% \mathrm{w} / \mathrm{v}$ or $1 \% v / v$ added to the headspace of $120 \mathrm{~mL}$ serum vials. Culture density measurements were recorded at $540 \mathrm{~nm}$ using a UV-1800 spectrophotometer (Shimadzu, Milton Keynes, UK).

\subsection{Genome Sequencing, Annotation, and Analysis}

DNA was extracted from Variovorax sp. WS11 cells grown using $10 \mathrm{mM}$ glucose using a Genomic Tip 100/G DNA isolation kit (Qiagen, Manchester, UK) and corresponding DNA buffers (Qiagen) according to the manufacturer's instructions. Genome sequencing was conducted by MicrobesNG (University of Birmingham, UK) using a combination of Illumina and Oxford Nanopore techniques. The final sequence, consisting of three contigs totalling $6.08 \mathrm{Mbp}$ and two plasmids of 1.1 and $1.3 \mathrm{Mbp}$, was uploaded to MicroScope, https://mage.genoscope.cns.fr/microscope (accessed on 20/05/2019) [46]. Amino acid sequences of isoprene metabolism proteins of Rhodococcus sp. AD45 were used to query the Variovorax sp. WS11 genome by tBLASTn, https://blast.ncbi.nlm.nih.gov/Blast.cgi (accessed on 13/11/2019) [47] and located a single gene cluster on megaplasmid 1 (Figure 1). This iso gene cluster was visually inspected using Artemis software (release 16.0.0, Cambridge, UK) [48] and the individual iso genes queried against the NCBI protein database and against reported Iso amino acid sequences by BLASTp (Table S3) [47].

\subsection{Mutagenesis of isoA}

isoA was deleted from Variovorax sp. WS11 by marker exchange mutagenesis according to Schäfer et al. [49]. Regions flanking iso $A$ were synthesised by Q5 high-fidelity polymerase (NEB, Hitchin, UK) using primers isoA_up_F (5'-ATCAGGATCCCATGGGCCCGGACATCCCATTCG-3')/isoA_up_R (5'-TGACTCTAGACGGCAGAAGCGGCTCTGCATCG-3') and isoA_down_F (5'-ATCATCTAGAAC 
ATGGCGCAGACCTACC-3')/isoA_down_R (5'-CTTAAAGCTTGATCGGCACCGTACACTC-3') using Variovorax sp. WS11 genomic DNA as the template. Each region was cloned into pK18mobsacB and a gentamicin resistance cassette was excised from p34S-Gm [50] and ligated into the XbaI site between the isoA flanking regions. Variovorax sp. WS11 was prepared for electroporation according to Pehl et al. [51] with minor modifications. In brief, Variovorax sp. WS11 was grown in $50 \mathrm{~mL}$ culture using $10 \mathrm{mM}$ glucose as the sole source of carbon and energy to an $\mathrm{OD}_{540}$ of 0.6 , chilled at $4{ }^{\circ} \mathrm{C}$ for $48 \mathrm{~h}$, then washed twice in chilled distilled water and finally resuspended in $1 \mathrm{~mL}$ of $10 \%(v / v)$ glycerol. Then, $100 \mu \mathrm{L}$ aliquots were transformed by electroporation with $100 \mathrm{ng}$ of the above construct, with pBBR1MCS-2 acting as a control for transformation efficiency. Exponential decay electroporation was used at $2.5 \mathrm{kV}, 2.5 \mu \mathrm{F}, 200 \Omega$ in a $2 \mathrm{~mm}$ gap cuvette. Cells were allowed to recover for $3 \mathrm{~h}$ in $1 \mathrm{~mL}$ Ewers medium containing $10 \mathrm{mM}$ glucose, pre-warmed to $30^{\circ} \mathrm{C}$ for recovery, cultures were maintained at 30 ${ }^{\circ} \mathrm{C}$ and shaken at $160 \mathrm{rpm}$. Transformed cells were then plated onto Ewers agar containing $10 \mathrm{mM}$ succinate and $50 \mu \mathrm{g} / \mathrm{mL}$ kanamycin, incubated at $30^{\circ} \mathrm{C}$ for 1 week to select for single-crossover of the suicide construct into the genome. The $\mathrm{pK} 18$ mobsacB backbone was removed from the genome by a second recombination event, selected for by spreading cells on Ewers agar containing $10 \mathrm{mM}$ succinate, $10 \mu \mathrm{g} / \mathrm{mL}$ gentamicin and $5 \%$ sucrose $(w / v)$, incubated at $30^{\circ} \mathrm{C}$ for 5 days. Deletion of $i s o A$ was confirmed by loss of kanamycin resistance with concomitant maintenance of gentamicin resistance, as well as verification by PCR using primers aacC1_F (5'-TCGTGAGTTCGGAGACGTAG-3')/isoB_R (5'-ACGTCGAAGCACTCCATCTC-3').

\subsection{Complementation of isoA Mutants}

Function of the iso metabolic cluster was restored by complementing the mutant with pBBR:isoAp:isoA-F plasmid. The sequence including isoA- $F$ with $256 \mathrm{bp}$ of its native flanking region was generated by PCR using isoAprom_fwd(5'-ATCAGGTACCTTCCGACATCGATCGCGCAACC-3') and isoFprom_rev( $5^{\prime}$-TGATGGATCCCGATGGCGATCAGCTCGTAGTG-3') under the assumption that the promoter would be located within the flanking region. The resulting product was digested with KpnI and BamHI. pBBR1MCS-2 [52] was digested with KpnI and BamHI and dephosphorylated using FastAP thermosensitive alkaline phosphatase (Thermo Scientific, Waltham, MA, USA). Both vector and digested PCR product were cleaned using a HighPure PCR product purification kit (Roche, Welwyn Garden City, UK) and ligated together with T4 DNA ligase (Thermo Scientific). The resulting mixture was used to transform E. coli Top10. Prepared plasmid DNA was sequenced and used to transform Variovorax sp. WS11 $\triangle i s o A$ as described earlier. Colonies were grown in Ewers medium containing 10 $\mathrm{mM}$ succinate and then sub-cultured into Ewers medium containing $1 \%(v / v)$ isoprene.

\subsection{Expression of iso Metabolic Genes in the Absence of Isoprene Monooxygenase}

Variovorax sp. WS11 $\triangle i s o A$ was grown to an $\mathrm{OD}_{540}$ of 0.6 in $50 \mathrm{~mL}$ Ewers medium containing 10 $\mathrm{mM}$ succinate. Cells were centrifuged at $7000 \times g$ for $10 \mathrm{~min}$ and washed in an equal volume of $50 \mathrm{mM}$ HEPES, pH 6.0. Three replicate cultures were resuspended in $50 \mathrm{~mL}$ Ewers medium without a carbon source and starved for $2 \mathrm{~h}$ at $30^{\circ} \mathrm{C}$ with shaking at $160 \mathrm{rpm}$. Three biological replicates were spiked with $10 \mathrm{mM}$ succinate, $1 \%$ isoprene, or $0.1 \%(v / v)$ epoxyisoprene and incubated for a further $2 \mathrm{~h}$ before extracting RNA using a hot phenol extraction method [53]. Samples were treated with RNase-free DNase (Qiagen) to remove contaminating DNA and RNA was purified with an RNeasy minikit (Qiagen). RNA quality was checked by agarose gel electrophoresis. RNA concentration was determined using a NanoDrop spectrophotometer (Thermo Fisher) and DNA contamination was checked for by PCR using 16S rRNA primers. Superscript III reverse transcriptase (Invitrogen, Waltham, MA, USA) was used to synthesise complementary cDNA according to the manufacturer's instructions using $500 \mathrm{ng}$ template RNA, primed by random hexamers (Fermentas, Waltham, MA, USA). Negative controls were prepared in the absence of reverse transcriptase. Quantitative PCR was performed in $20 \mu \mathrm{L}$ reactions using a StepOnePlus instrument (Applied Biosystems, Foster City, CA, USA) using Sensifast SYBR HI-ROX master mix (BioLine, London, UK) with $2 \mu \mathrm{L}$ template cDNA. iso $G$ was amplified by 
qisoG_F (5'-AAGACCATGAGCAACCAGGA-3') and qisoG_R (5'-GCCGTTGTTCTCGACTTCAA-3'), and $r p o B$ as a reference gene was amplified by qrpoB_F (5'-TGCAGGCCATTTACACCAAC-3'), qrpoB_R (5'-TTGAACTTCATGCGACCGAC-3'). Changes in iso gene expression were calculated relative to the rpoB reference gene according to the comparative $C_{\mathrm{T}}$ method, and further analysed by comparison of normalised $C_{T}$ values between each carbon source [54].

\subsection{Differential Expression of iso Metabolic Genes under Different Growth Conditions}

Variovorax sp. WS11 was grown in triplicate in $20 \mathrm{~mL}$ Ewers medium containing 1\% (v/v) isoprene, $10 \mathrm{mM}$ glucose or $10 \mathrm{mM}$ glucose $+1 \%$ isoprene. Cells were harvested by centrifugation at $7000 \times g$ for $10 \mathrm{~min}$ and resuspended to an $\mathrm{OD}_{540}$ of $10.0 \mathrm{in} 1 \mathrm{~mL}$ HEPES, pH 6.0. Cell suspensions were sealed in $30 \mathrm{~mL}$ vials with butyl rubber stoppers and pre-heated to $30^{\circ} \mathrm{C}$ in a water bath, shaken at $160 \mathrm{rpm}$ for $3 \mathrm{~min}$ before adding $300 \mathrm{ppmv}$ isoprene. After incubation for $1 \mathrm{~min}, 50 \mu \mathrm{L}$ of headspace gas was sampled using a gas-tight syringe (Agilent, Cheadle, UK) and isoprene was measured using a Fast Isoprene Sensor (Hills-Scientific, Boulder, CO, USA) at $3 \mathrm{~min}$ intervals for $1 \mathrm{~h}$. Depletion of isoprene was used to calculate the rate of isoprene uptake by cells grown under each condition.

Variovorax sp. WS11 was prepared for RNA extraction by growing in $50 \mathrm{~mL}$ Ewers medium in $120 \mathrm{~mL}$ vials using the same substrate combinations described above. Cells were harvested at an $\mathrm{OD}_{540}$ of 0.6 by centrifugation at $7000 \times \mathrm{g}$ for $10 \mathrm{~min}$, then total RNA was extracted as described above. iso $A$ was amplified using qiso $A \_F\left(5^{\prime}\right.$-GATGTCTCGTTCTGGCGTTC-3'), qiso $A \_R$ (5'-ACCCGTAGTCCTTCATCGTG-3'). Expression of $i s o A$ under each growth condition was calculated relative to expression of $r p o B$.

\subsection{Oxidation of Alkenes by Variovorax sp. WS11 Grown under Different Conditions}

Variovorax sp. WS11 was grown in 2 litre flasks in $400 \mathrm{~mL}$ Ewers medium containing either $10 \mathrm{mM}$ glucose or $10 \mathrm{mM}$ succinate as the sole source of carbon and energy. Cells were grown to an $\mathrm{OD}_{540}$ of 0.6 , harvested by centrifugation at $7000 \times g$ for $10 \mathrm{~min}$ and resuspended in $4 \mathrm{~mL}$ of $50 \mathrm{mM} \mathrm{HEPES}, \mathrm{pH}$ 6.0. Cells were drop frozen in liquid nitrogen and stored at $-80{ }^{\circ} \mathrm{C}$ until required. Variovorax sp. WS11 was grown in 4 litres of Ewers medium using isoprene as the sole source of carbon and energy in a 4 litre working volume fermentor (Electrolab, Tewkesbury, UK) with constant maintenance of optimal growth conditions $\left(30^{\circ} \mathrm{C}, 160 \mathrm{rpm}, \mathrm{pH}\right.$ 6.0) and air flow $(2.4 \mathrm{~L} / \mathrm{min})$. Isoprene was supplied by bubbling air $\left(1 \mathrm{~mL} \mathrm{~min}{ }^{-1}\right)$ through a small volume of liquid isoprene contained in a $30 \mathrm{~mL}$ vial, held at $0{ }^{\circ} \mathrm{C}$ on ice (Figure S1). Purity was routinely checked by a combination of microscopy and growth on R2A agar (Oxoid, Basingstoke, UK). Cells were harvested every $48 \mathrm{~h}$ and drop frozen under the conditions described above. Substrate oxidation rates were tested for cells prepared under each condition using a Clark oxygen electrode [55]. Substrate-induced rates of oxygen uptake were calculated according to the previously described method [56]. Drop-frozen Variovorax sp. WS11 cells from each of the above growth conditions were thawed, starved at room temperature for $2 \mathrm{~h}$, and resuspended in $3 \mathrm{~mL}$ of 50 mM HEPES, $\mathrm{pH} 6.0$, to an $\mathrm{OD}_{540}$ of 2.0 and warmed to $30{ }^{\circ} \mathrm{C}$ with stirring. Oxidation substrates were added to $100 \mu \mathrm{M}$ as saturated solutions in water. Endogenous rates of oxygen uptake were subtracted from oxygen uptake after substrate addition to calculate substrate-induced rates of oxygen uptake for each growth condition using three biological replicates.

\subsection{Inhibition of IsoMO and sMMO Activity by Alkynes}

C2-C4 alkynes were added from gaseous stocks. Gas-liquid partitioning was calculated according to the Henry's Law constants $\left(H^{c p}\right)$ of acetylene $\left(4.1 \times 10^{-4} \mathrm{~mol} / \mathrm{m}^{3} \mathrm{~Pa}\right)$, propyne $\left(9.3 \times 10^{-4} \mathrm{~mol} / \mathrm{m}^{3}\right.$ $\mathrm{Pa})$, and butyne $\left(5.4 \times 10^{-4} \mathrm{~mol} / \mathrm{m}^{3} \mathrm{~Pa}\right)$ [57] to enable addition of each alkyne to $50 \mu \mathrm{M}$. C6-C8 alkyne stock solutions were prepared as $1 \%(v / v)$ in dimethyl sulfoxide (DMSO). Variovorax sp. WS11 was used for isoprene uptake assays at an $\mathrm{OD}_{540}$ of 1.0 in $1 \mathrm{~mL}$ HEPES (50 mM, pH 6). Isoprene-grown cells were placed in $30 \mathrm{~mL}$ serum vials sealed with butyl rubber stoppers and pre-warmed for 3 min at $30{ }^{\circ} \mathrm{C}$, with shaking at $160 \mathrm{rpm}$. The $300 \mathrm{ppm}$ isoprene was added and Variovorax sp. WS11 was 
incubated for a further 1 min before sampling $50 \mu \mathrm{L}$ headspace as previously described. Samples were taken at $5 \mathrm{~min}$ intervals for $45 \mathrm{~min}$. Alkynes were added (to an aqueous concentration of $50 \mu \mathrm{M}$ ) as gases to the headspace or as concentrated stock in DMSO immediately after sampling timepoint 3. The inhibited rate (timepoints 5-10) was calculated relative to the initial rate of isoprene oxidation (timepoints 1-3). Samples without alkyne and with DMSO alone were used as controls. Each assay was performed using three biological replicates. With the exception of C6-C8 alkynes, results are reported as the mean of these three replicates \pm standard deviation. C6-C8 alkynes were presented as the mean inhibition by DMSO $(1.4 \pm 7.2 \%)$ subtracted from the mean inhibition by alkyne \pm standard deviation about the means.

Methylococcus capsulatus (Bath) was grown in a 2 litre fermentor (New Brunswick, Eppendorf, Stevenage, UK) using methane as the sole source of carbon and energy as previously described [58], with the exception that this culture was grown in batch mode. The switch from expression of particulate to soluble methane monooxygenase was monitored using the naphthalene assay [59]. Cells were drop frozen in liquid nitrogen and stored at $-80{ }^{\circ} \mathrm{C}$. When thawed, cells were resuspended in $1 \mathrm{~mL}$ of $50 \mathrm{mM}$ phosphate, and pH $7.020 \mathrm{mM}$ sodium formate was included as a source of reducing power. Isoprene uptake assays were performed as described above, with cells pre-heated to $30{ }^{\circ} \mathrm{C}$ and the rate of isoprene uptake calculated over $45 \mathrm{~min}$. As a proxy for the rate of methane oxidation by sMM, the conversion of propylene to propylene oxide was used as a measure of typical sMMO activity, with propylene oxide formation detected by gas chromatography as previously described [60]. Alkyne inhibition of isoprene or propylene oxidation by sMMO was tested by the above method using $50 \mu \mathrm{M}$ acetylene or $50 \mu \mathrm{M}$ octyne. Since DMSO alone also had an inhibitory effect on the sMMO (but not on IsoMO) and octyne was added as a solution in DMSO, the inhibition of propylene oxidation and isoprene oxidation attributable to DMSO, $25.2 \pm 6 \%$ and $27.4 \pm 5 \%$ respectively, was subtracted from the inhibition of substrate oxidation due to octyne.

\subsection{Heterologous Expression of Isoprene Monooxygenase}

iso A-F was amplified by Q5 high-fidelity polymerase using primers iso $A \_f w d\left(5^{\prime}\right.$-ATGAACATGT CCTTGCTGAGCCGAGACGACTG-3') and isoF_rev (5'-ATCAGGATCCCGATGGCGATCAGCTC GTAG-3'). The purified PCR product was digested with BamHI and PciI and ligated with pTipQC1 [61] that had been digested with BamHI and NcoI. The resulting vector (pTipQC1:iso11) was used to transform Rhodococcus sp. AD45-id [28] by electroporation as previously described [28]. IsoMO expression was induced as previously described [28]. In brief, Rhodococcus sp. AD45-id containing either pTipQC1 or pTipQC1:iso11 was grown in $120 \mathrm{~mL}$ serum vials sealed with butyl rubber stoppers, in $20 \mathrm{~mL}$ Ewers medium containing $10 \mathrm{mM}$ succinate to an $\mathrm{OD}_{540}$ of 0.6 and induced with $1 \mu \mathrm{g} / \mathrm{mL}$ thiostrepton (prepared as $20 \mathrm{mg} / \mathrm{mL}$ stock in DMSO). Induced cells were incubated for $16 \mathrm{~h}$ at $30^{\circ} \mathrm{C}$ with shaking at $160 \mathrm{rpm}$ and then centrifuged at $7000 \times \mathrm{g}$ for $10 \mathrm{~min}$. Pellets were resuspended to an $\mathrm{OD}_{540}$ of 10.0 in $50 \mathrm{mM}$ phosphate buffer ( $\mathrm{pH}$ 7.0). Cells were tested for isoprene consumption using the Fast Isoprene Sensor as described earlier. Three biological replicates were used for each assay.

\subsection{Accession Number}

The chromosomal and megaplasmid sequences of Variovorax sp. WS11 have been deposited at DDBJ/ENA/Genbank under the accession JAAGOW000000000. The version described in this paper is version JAAGOW010000000. The genomic nucleotide sequence of Ramlibacter sp. WS9 is available under accession number NZ_RKMB00000000.

\section{Results and Discussion}

\subsection{Isolation of Variovorax sp. WS11 from Willow Soil}

Variovorax sp. WS11 was previously isolated from willow soil samples by continuously enriching in the presence of 25 ppmv isoprene, as a comparatively low concentration [28]. Variovorax sp. WS11 
was one of two Gram-negative isoprene-degrading bacteria isolated from this environment, together with Ramlibacter sp. WS9 [30], and was shown by 16S rRNA gene sequencing to be a novel species of Variovorax. Phylogenetic analysis of the 16S rRNA gene of Variovorax sp. WS11 indicates that it is most related to Variovorax sp. RA8 (Figure S2), with 16S rRNA nucleotide sequence identity of 99.9\% with $99 \%$ query cover [62]. Variovorax sp. RA8 was isolated from Japanese river sediment and has been noted for its ability to degrade the herbicide linuron [63].

\subsection{Genome sequencing and Analysis}

The genome of Variovorax sp. WS11 was sequenced by a combination of Illumina and Oxford Nanopore techniques and annotated using the MicroScope Microbial Genome Annotation and Analysis Platform [46]. Two megaplasmids of 1.1 and 1.3 Mbp were identified (Table S1). The sequence of the chromosome was comprised of three contigs totalling $6.08 \mathrm{Mbp}$. Relatively little pseudogenisation was detected, with only 26 pseudogenes detected by the MicroScope annotation pipeline [46]. The GC content of the Variovorax sp. WS11 chromosome was higher than that of both megaplasmids, measuring $68.2 \%$ compared to $64.4 \%$ and $66.6 \%$ for megaplasmids 1 and 2 , respectively (Table S1). Of 5930 predicted coding sequences, 1972 were not assigned a function by the RAST annotation pipeline, http://rast.theseed.org/FIG/rast.cgi (accessed on 16/05/2019) [64-66]. RAST subsystems analysis predicted that megaplasmids 1 and 2 dedicate a large portion of their coding sequences to metabolic processes (Table S1). While $2.1 \%$ of the chromosomal coding sequences had predicted functions relating to fatty acids, lipids and isoprenoids, megaplasmids 1 and 2 had $5.8 \%$ and $5.7 \%$, respectively, of their total coding sequences dedicated to this subsystem. In total, $4.6 \%$ of chromosomal genes and $4.5 \%$ of megaplasmid 1 genes were predicted to encode functions relating to carbohydrate metabolism, while $7.5 \%$ of megaplasmid 2 genes related to this subsystem (Table S1). Megaplasmid 2 was also predicted to encode asparaginyl-tRNA, while all other genes involved in tRNA biosynthesis are located on the chromosome.

\subsubsection{The Genome of Variovorax sp. WS11 Encodes Multiple Putative Oxygenase Gene Clusters}

A combination of visual inspection, tBLASTn analysis using reference genes [47], and annotation by the MicroScope pipeline [46] identified an abundance of partial and apparently complete oxygenase gene clusters in the genome of Variovorax sp. WS11. One such gene cluster was predicted to encode a methanesulfonate monooxygenase $(m s m A B C D)$, located on the chromosome, which resembled the well-characterised msm cluster of Methylosulfonomonas methylovora [67]. The case for this putative gene cluster encoding an active methanesulfonate monooxygenase (MsaMO) was strengthened by the presence of a characteristic Rieske-type [2Fe-2S] motif ( $\left.\mathrm{CXH}-\mathrm{X}_{26}-\mathrm{CXXH}\right)$ within $m s m A$ [67]. $m s m B$, predicted to encode the hydroxylase $\beta$-subunit, was located immediately downstream of $m s m A$ (Figure S3). Likewise, $m s m C$ and $m s m D$, encoding the ferredoxin and reductase components respectively, were positioned downstream of $m s m A B$. However, the putative MsaMO gene cluster in Variovorax sp. WS11 lacked the typical transporter genes, $m s m E F G H$, expected to be in close proximity to $m s m A B C D$ [68]. Instead, a putative proline/betaine transporter and a putative sulphite exporter were located downstream of $m s m D$. Homologs of $m s m E F G H$ were detected elsewhere on the genome by tBLASTn analysis using the genes of M. methylovora as queries. Variovorax sp. WS11 was inoculated in Ewers medium with $5 \mathrm{mM}$ sodium methanesulfonate, or $5 \mathrm{mM}$ ethanesulfonic acid but no growth was observed, confirming that the putative MsaMO genes alone were insufficient to support growth under the conditions tested. Secondly, several tauD genes were identified in both the chromosome and megaplasmid 2 of Variovorax sp. WS11, predicted to encode $\alpha$-ketoglutarate-dependent taurine dioxygenase (Figure S3). While none of these were in proximity to the corresponding $\operatorname{tau} A B C$ genes which encode an ABC-type transporter required for uptake of taurine into the cell [69], tauABC were identified elsewhere on megaplasmid 2. Variovorax sp. WS11 was capable of utilising taurine as a sole source of carbon and energy (Table S2), indicating that an active taurine dioxygenase (TauD) was expressed or that an alternative oxygenase capable of taurine metabolism was expressed. Two other 
oxygenase gene clusters were identified, each predicted to encode a salicylate 5-hydroxylase (nagGH) (Figure S3). Each putative salicylate 5-hydroxylase gene cluster had differences in organisation. Both were located on megaplasmid 2 but in opposing orientations and distant from each other, and each contained a copy of a putative NAD(P)-dependent reductase (nagAa) and a ferredoxin (nagAb) (Figure S3). Salicylate 5-hydroxylase is often utilised as part of the wider naphthalene degradation pathway, with naphthalene oxidation by naphthalene 1,2-dioxygenase (nagAcAd) to salicylate comprising the upper part of the pathway [70]. The lack of genes involved in the subsequent salicylate oxidation (nahAa-nahAD) [71] in the genome of Variovorax sp. WS11 made it unlikely for growth on salicylate or naphthalene to occur, and neither $5 \mathrm{mM}$ naphthalene or $5 \mathrm{mM}$ sodium salicylate supported growth of Variovorax sp. WS11 (Table S2).

3.2.2. The iso Metabolic Gene Cluster of Variovorax sp. WS11 is Distinct from that of Rhodococcus sp. AD45

Using the translated amino acid sequences of the iso metabolic genes of Rhodococcus sp. AD45 as tBLASTn query sequences, putative iso metabolic genes were located on a single gene cluster on megaplasmid 1 in Variovorax sp. WS11 (Figure 1, Table S1) [47]. To the best of our knowledge, this is the first isolated species of Variovorax which contains the full iso metabolic gene cluster, as determined by tBLASTn analysis of the critical isoA gene against the NCBI protein database [47]. Visual inspection using Artemis software revealed a similar organisation of iso metabolic genes in Variovorax sp. WS11 as found in Rhodococcus sp. AD45 [48]. Aside from isoA, the amino acid identities of translated isoB-J genes of Variovorax sp. WS11 and Rhodococcus sp. AD45 shared homology ranging from approximately 40-60\% (Table S3). tBLASTn analysis was conducted using the translated iso amino acid sequences of Ramlibacter sp. WS9, a second Gram-negative isoprene degrader isolated from willow soil [30]. Alignment of amino acid sequences of iso $A$ of known isoprene-degrading bacteria with reference oxygenase alpha subunits of other SDIMO reveals an interesting evolutionary relationship (Figure 2). A number of Gram-positive actinobacteria have been isolated with the ability to degrade isoprene, and the $i s o A$ sequences of these organisms are typically grouped together when phylogenetically analysed. Variovorax sp. WS11 and Ramlibacter sp. WS9, the first reported Gram-negative isoprene degraders from soil, occupy a distinct branch of the phylogenetic tree, more closely related to the alkene monooxygenase alpha subunit xamoA of Xanthobacter strain Py2. The isoA sequences of Variovorax sp. WS11 and Ramlibacter sp. WS9 share 92\% amino acid identity, while the former only shares $73 \%$ amino acid identity with the isoA sequence of Rhodococcus sp. AD45 (Table S3). Enzymes involved in subsequent steps in isoprene metabolism following the conversion of isoprene to epoxyisoprene by IsoMO, encoded by isoGHIJ, are duplicated in Rhodococcus sp. AD45 [45]. No duplication of isoGHIJ was found in Variovorax sp. WS11 (Figure 1). This also appears to the be case for other Gram-negative isoprene-degrading bacteria, including Ramlibacter sp. WS9 (Figure 1), and for a few Gram-positive isoprene-degrading bacteria [28].

Interestingly, Variovorax sp. WS11 lacks glutathione biosynthesis genes in the isoprene gene cluster. Glutathione is important in many bacteria as a means of protection against toxic and oxidative stresses during aerobic growth, but Gram-positive bacteria typically use alternative low molecular weight thiols such as mycothiol, and do not produce glutathione [72]. Despite this, previous work strongly indicated the importance of glutathione in isoprene degradation by Rhodococcus sp. AD45, since IsoI detoxifies the epoxyisoprene produced from isoprene by IsoMO by producing a glutathione conjugate, 1-hydroxy-2-glutathionyl-2-methyl-3-butene (HGMB) [22-24]. The styrene oxidation pathway of the Gram-positive strain Gordonia rubripertincta CWB2 also involves glutathione [73]. In common with other Gram-negative bacteria, Variovorax spp. produce glutathione as a core metabolic process, and all predicted glutathione biosynthesis genes are located on the chromosome. It was predicted that Rhodococcus sp. AD45 gained the genes required for glutathione biosynthesis ( $g$ sh $A B$ ), located in the iso metabolic gene cluster (Figure 1), by horizontal gene transfer [74]. Further differences in the organisation of the iso metabolic gene cluster include the insertion of a single copy of aldH between 
isoJ and isoA in Variovorax sp. WS11, a trait conserved in Ramlibacter sp. WS9 [30], while Rhodococcus sp. AD45 contains two distinct ald $H$ genes located at opposite ends of the iso gene cluster. The single ald $H$ gene in the iso metabolic gene cluster of Variovorax $\mathrm{sp}$. WS11 is most closely related to aldH1 in Rhodococcus sp. AD45, with $52.7 \%$ amino acid identity (97\% coverage) compared to only $26.1 \%$ amino acid identity with ald 2 (69\% coverage), predicted to encode a 4-hydroxymuconic semialdehyde dehydrogenase $[47,75]$. The roles of aldH1 and ald $\mathrm{H} 2$ in isoprene metabolism are currently unconfirmed, although the tadD gene of Rhodococcus sp. PD630, which shares $81 \%$ amino acid identity with aldH1 of Rhodococcus sp. AD45 [45], encodes a glyceraldehyde 3-phosphate dehydrogenase [76]. Rhodococcus sp. AD45 contains two putative regulatory genes annotated as marR, with only the divergently transcribed marR2 being upregulated in response to isoprene [45]. The closest marR homolog in Variovorax sp. WS11 also resides on megaplasmid 1 but is $200 \mathrm{kbp}$ in distance from the iso gene cluster. Instead, two putative LysR-type transcriptional regulators, annotated as $d m l R$, are divergently transcribed from the iso cluster in Variovorax sp. WS11 (Figure 1), suggesting that this novel isolate employs an alternative method of regulation of isoprene metabolism. The iso metabolic gene cluster of Ramlibacter sp. WS9 also contains a single copy of $d m l R$ upstream of $i s o G$, potentially indicating that these closely related isoprene degraders share a similar method of regulating the expression of iso metabolic genes. Variovorax sp. WS11 was selected as a Gram-negative model for the study of isoprene metabolism primarily due to two factors. The growth rate of Variovorax sp. WS11 on isoprene is greater than that of Ramlibacter sp. WS9, measuring $0.052 \pm 0.004 \mathrm{~h}^{-1}$ [28]. Secondly, as genetics systems have previously been established for Variovorax paradoxus EPS [51], we set out to optimise these techniques to allow the manipulation of Variovorax sp. WS11.

\section{Rhodococcus sp. AD45}

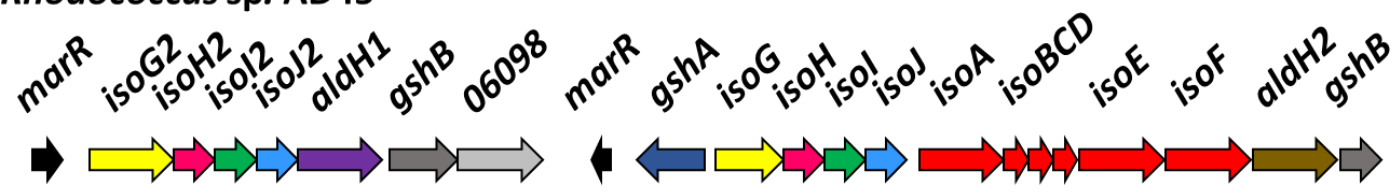

Variovorax sp. WS11

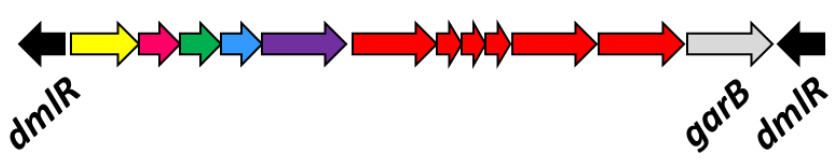

Ramlibacter sp. WS9

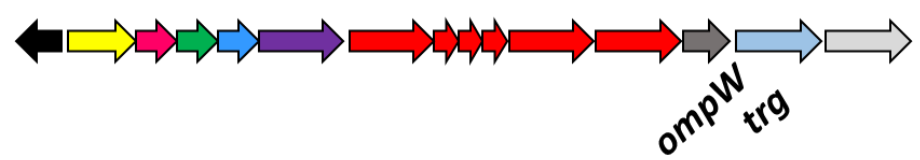

Figure 1. Comparison of iso metabolic gene cluster organisation of the reference isoprene degrader Rhodococcus sp. AD45 with Variovorax sp. WS11 and Ramlibacter sp. WS9. 


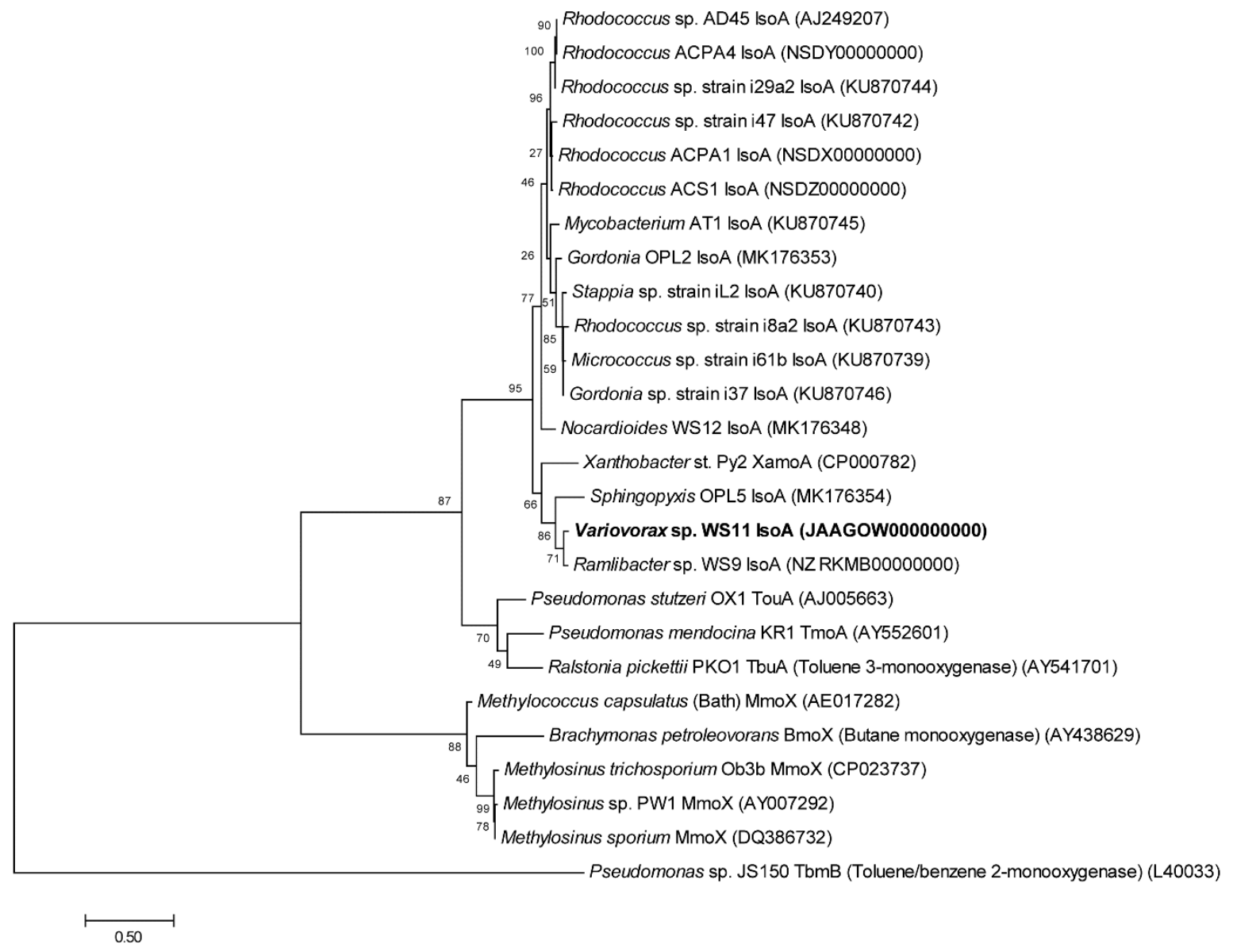

Figure 2. Phylogenetic organisation of isoprene monooxygenase oxygenase alpha-subunit (iso $A$ ) against reference soluble di-iron monooxygenase (SDIMO) amino acid sequences with accession numbers in brackets. The tree was drawn using the Maximum Likelihood method using Mega7 [77]. Bootstrap values (500 replications) are shown at the nodes. All positions containing gaps and missing data were eliminated. Branch lengths are measured in the number of substitutions per site.

\subsection{Functional Confirmation and Substrate-Induced Transcription of iso Metabolic Genes}

Functional confirmation of putative isoprene monooxygenase-encoding genes has previously been achieved by expression of $i s o A-F$ in Rhodococcus sp. AD45-id, a strain cured of the megaplasmid containing the isoprene gene cluster, which is therefore unable to metabolise isoprene [28]. The IsoMO genes (isoA-F) from Variovorax sp. WS11 were cloned into the Rhodococcus expression vector pTipQC1 [61], under the control of a thiostrepton-inducible promoter. Whole-cells of Rhodococcus sp. AD45-id containing pTipQC1:iso11 were capable of oxidising isoprene at $38 \%$ of the wild-type rate when induced, in contrast to cells transformed with pTipQC1 without an isoA-F insert (data not shown), confirming that the iso metabolic gene cluster identified in Variovorax sp. WS11 was active.

To establish beyond doubt that the isoprene monooxygenase was required for isoprene metabolism in Variovorax sp. WS11, targeted mutagenesis was used. Deletion of iso $A$ abolished all growth on isoprene (Figure 3), but growth on glucose and succinate remained similar to that of the wildtype (data not shown). The mutant strain Variovorax sp. WS11 $\Delta i s o A$ could be complemented for growth on isoprene by expression of $i s o A-F$ including 256 nucleotides $5^{\prime}$ of $i s o A$, containing the full intergene region, from pBBR1MCS-2, restoring growth on isoprene to approximately wild-type levels (Figure 3). Since isoGHIJ encode the subsequent enzymes of the pathway, including those required for detoxification of epoxyisoprene, it was anticipated that the whole cluster isoGHIJABCDEF would be co-induced during conditions which activated isoprene metabolism. The first gene of the cluster, isoG, was 
selected to determine the levels of gene transcription in response to the potential inducers isoprene and epoxyisoprene. Gene expression was studied in Variovorax sp. WS11 $\triangle i s o A$ as this strain is unable to metabolise isoprene, meaning that any upregulation in the presence of isoprene could not be explained by any regulatory effects of subsequent products of isoprene metabolism. RT-qPCR analysis revealed that, in WS11 $\triangle i s o A$, isoG was significantly upregulated by both isoprene (6.3-fold) and epoxyisoprene (146-fold) after $2 \mathrm{~h}$ of exposure to the inducing substrate (Figure S4). This contrasts with our knowledge of Rhodococcus sp. AD45, in which epoxyisoprene induced gene expression, but isoprene itself had no inducing effect [45]. Given the significant increase in upregulation by epoxyisoprene compared to isoprene, it is likely that epoxyisoprene has a much greater affinity for regulatory elements specific to the iso metabolic gene cluster, although downstream products of epoxyisoprene metabolism, such as HGMB or GMBA or an as-yet unidentified intermediate, may act as the primary inducer of iso gene expression in Variovorax sp. WS11.

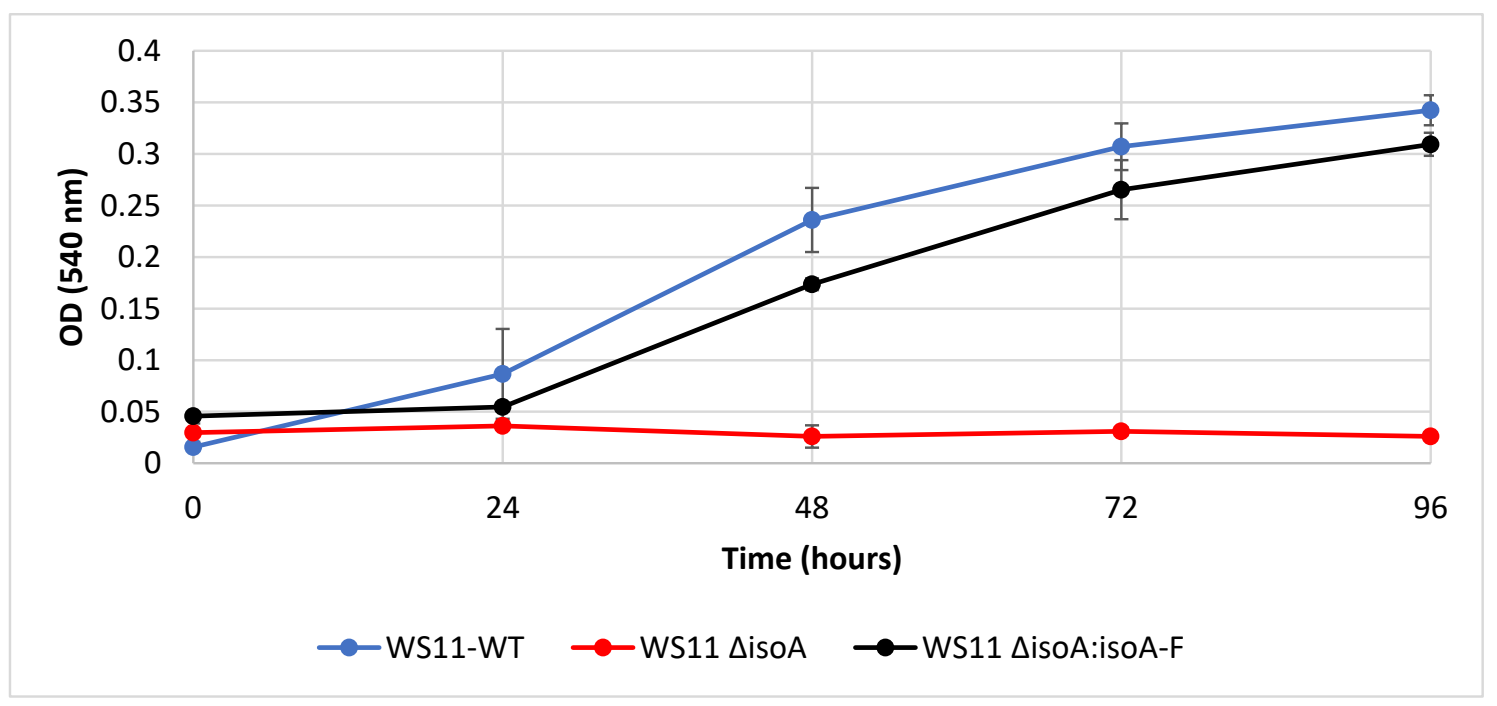

Figure 3. Wild-type Variovorax sp. WS11 (WS11-WT) and complemented isoA mutant (WS11 $\triangle i s o A: i s o A-F)$ grow to a similar culture density when provided with $1 \% v / v$ isoprene, but iso $A$ deletion strain (WS11 $\triangle i s o A$ ) cannot grow on isoprene. Time points are the mean of three biological replicates and the error bars represent the standard deviation.

\subsection{Differential Expression of a Broad-Range SDIMO Active with Branched Hydrocarbons}

Growth of Variovorax sp. WS11 was sustained by a range of sugars, carboxylic acids and amino acids, but not by any alkenes tested with the exception of isoprene (Table S2). When Variovorax sp. WS11 was grown solely on isoprene, whole cells oxidised $1.51 \pm 0.64 \mathrm{nmoL}$ isoprene/min $/ \mathrm{mg}$, but when grown on glucose or a combination of glucose and isoprene, whole cells did not oxidise isoprene. RT-qPCR analysis of iso $A$ expression under the same growth conditions confirmed that iso $A$ was upregulated significantly when Variovorax sp. WS11 was grown on isoprene, with a relative expression value of 582 when compared to isoA expression by cells grown using glucose, but expression of iso $A$ was repressed during growth on glucose or a combination of glucose and isoprene (Figure S5).

SDIMOs are typically capable of oxidising a wide range of organic substrates. The substrate specificity of IsoMO was investigated by comparing the substrate oxidation profile of Variovorax $\mathrm{sp}$. WS11 when grown on glucose, succinate or isoprene. Cells grown on succinate and glucose were only able to oxidise sugars and carboxylic acids, while isoprene-grown cells were also able to oxidise a wide range of alkenes (Figure 4). The substrate oxidation profile of Variovorax sp. WS11 indicated a positive correlation between rate of oxidation and carbon chain length, with octene and dodecene being oxidised at very high rates compared to ethylene and propylene (Figure 4). A consistent trend is seen when comparing oxidation of branched and unbranched hydrocarbons; isoprene (2-methyl-1,3-butadiene) 
and 3-methyl-1,4-pentadiene are each oxidised at higher rates than 1,3-butadiene and 1,4-pentadiene, respectively. It is also curious that IsoMO is incapable of oxidising benzene but all branched derivatives (ethylbenzene, propylbenzene, toluene, $o$-xylene, styrene) are oxidised. The same is observed for cyclohexene and methyl-cyclohexene, with activity only being observed in the branched derivative.

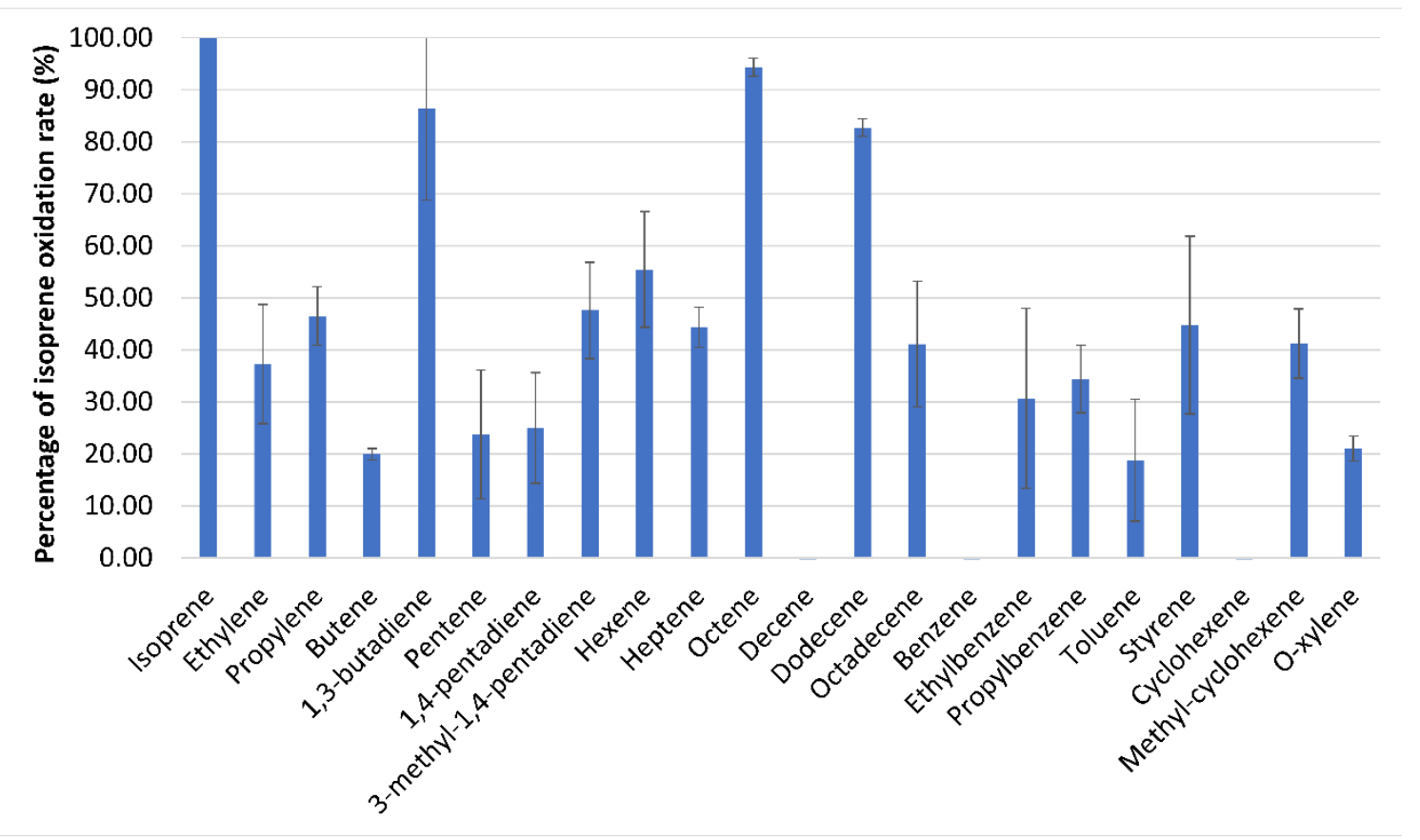

Figure 4. Relative rates of substrate-dependent oxygen uptake by isoprene-grown Variovorax sp. WS11, where $100 \%$ is $31.2 \mathrm{nmoL} / \mathrm{min} / \mathrm{mg}$ dry weight.

\subsection{Inhibition by Alkynes Indicates that IsoMO is a Distinct SDIMO}

Alkynes have been known to act as inhibitors of SDIMO activity for many years. Methane oxidation by the soluble methane monooxygenase (sMMO) of Methylococcus capsulatus (Bath) was completely inhibited by relatively low concentrations of acetylene [78,79], and this inhibition was dependent on turnover of acetylene at the active site [79]. It was previously observed that the rate of substrate oxidation by the sMMO of M. capsulatus (Bath) decreased with increasing carbon chain length [60]. Therefore, due to the decreased rate of substrate turnover, it may be the case that longer-chain alkynes exert a weaker inhibitory effect on sMMO activity than acetylene.

\subsubsection{Inhibition of IsoMO Correlates with Increasing Alkyne Chain Length}

Alkynes (C2-C8) were tested for their ability to inhibit isoprene oxidation by IsoMO in Variovorax sp. WS11. The rate of isoprene oxidation was decreased by $6.5 \%$ by $50 \mu \mathrm{M}$ acetylene, demonstrating that acetylene is a significantly less potent inhibitor of IsoMO than of sMMO (Figure 5). Inhibition increased significantly with increasing chain length; propyne and butyne inhibited 53.1 and $87.4 \%$ of isoprene oxidation activity, respectively. Hexyne and heptyne each inhibited to a similar degree as butyne, with 83.3 and $88.2 \%$ inhibition, respectively, while octyne was the most potent inhibitor tested, causing $94.7 \%$ inhibition of isoprene oxidation under the conditions tested (Figure 5). DMSO had no inhibitory effect on isoprene oxidation by IsoMO, validating the observed inhibition of IsoMO by C6-C8 alkynes. 


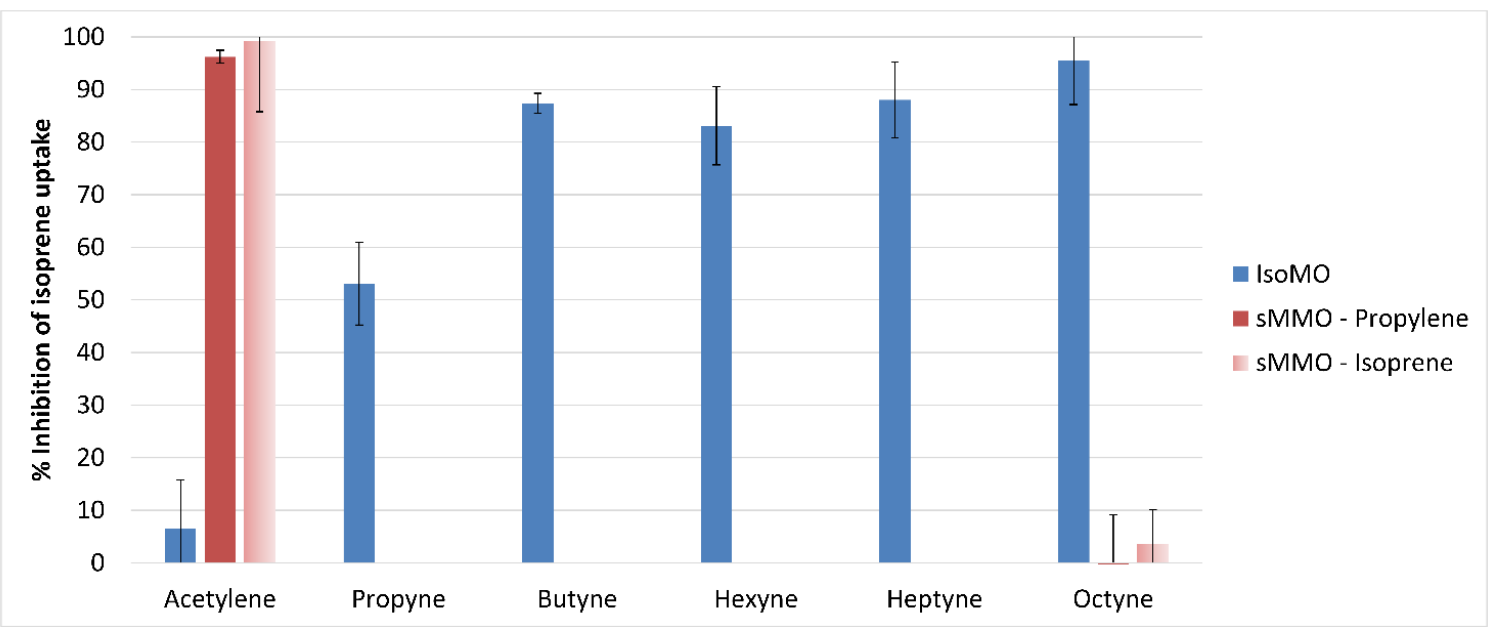

Figure 5. Differential inhibition of IsoMO and soluble methane monooxygenase (sMMO) by C2-C8 alkynes $(50 \mu \mathrm{M})$, where DMSO acts as a control for C6-C8 alkynes since C6-C8 alkynes were dissolved in DMSO before addition.

\subsubsection{IsoMO is Distinct from the Well-Characterised sMMO}

The sMMO from Methylococcus capsulatus (Bath) was selected as a comparative SDIMO for inhibition by alkynes due to the pre-existing knowledge of the potency of acetylene as an inhibitor of this sMMO [78,79], and since the sMMO of Methylocella silvestris BL2 has previously been reported to co-oxidise isoprene [80], although neither of these methanotrophs can grow on isoprene. Therefore, the sMMO of M. capsulatus (Bath) was tested and confirmed to co-oxidise isoprene with an initial rate of $1.38 \pm 0.15 \mathrm{nmoL} / \mathrm{min} / \mathrm{mg}$ dry weight. A total of $50 \mu \mathrm{M}$ acetylene and $50 \mu \mathrm{M}$ octyne were the least potent and most potent inhibitors (respectively) of isoprene oxidation by the IsoMO of Variovorax sp. WS11 under the conditions tested (Figure 5) and were also tested as inhibitors of isoprene oxidation by sMMO. The assay conditions were first verified by testing the co-oxidation of propylene to propylene oxide by sMMO. On average, $96.2 \%$ of propylene oxidation was inhibited by $50 \mu \mathrm{M}$ acetylene, confirming the efficacy of this inhibitor and immediately differentiating IsoMO from sMMO, compared to $99.1 \%$ of isoprene oxidation by sMMO by $50 \mu \mathrm{M}$ acetylene, 15-times its inhibition of isoprene oxidation by IsoMO. $50 \mu \mathrm{M}$ octyne did not inhibit propylene oxidation by sMMO under these conditions, but approximately $5.7 \%$ of isoprene oxidation was inhibited by octyne (Figure 5). These data demonstrate the effectiveness of these alkyne inhibitors to distinguish between true isoprene degraders and bacteria which co-oxidise isoprene using an alternative SDIMO.

\section{Conclusions}

This study describes the genetic and biochemical characterisation of a new model bacterium for isoprene degradation, the Gram-negative bacterium Variovorax sp. WS11. The genetic tractability of this model organism was demonstrated, and the use of a Gram-negative isolate may aid in the functional characterisation of the downstream steps of the isoprene metabolic pathway, such as the function of $i s o G$, isoJ, and ald $H$. The iso metabolic gene cluster in Variovorax sp. WS11 was located on a megaplasmid, suggesting that this second well-characterised iso gene cluster was acquired through horizontal gene transfer. The iso metabolic gene cluster displayed significant variation from the original model of Rhodococcus sp. AD45, such as the lack of duplications of isoGHIJ and aldH, and the lack of glutathione biosynthesis genes. Functionality of $i s o A-F$ was confirmed by expression in Rhodococcus sp. AD45-id, and the dependency of Variovorax sp. WS11 on iso genes was confirmed by knockout of isoA. Two putative LysR-type transcriptional regulators may play a role in regulating isoprene metabolism and remain the subjects of further study. IsoMO oxidised a wide range of alkenes, with a tendency to display increased activity with branched hydrocarbon chains when compared 
to their unbranched counterparts. Inhibition of isoprene oxidation by $50 \mu \mathrm{M}$ acetylene and $50 \mu \mathrm{M}$ octyne differed significantly between IsoMO and sMMO. An estimated 2.4 million tons of isoprene are degraded each year by soils $[18,19]$. The proportion of isoprene uptake by bona fide isoprene degraders compared to bacteria which co-oxidise isoprene using other SDIMOs is currently unknown. Future experiments using soil samples can now be carried out to determine the efficacy of this test in situ with environmental samples, with a view to quantifying the contributions of different groups of SDIMO-utilising organisms in the removal of isoprene from the biosphere. This study provides a basis for the continued investigations into the role of bacteria in the biogeochemical cycling of isoprene using a comparative Gram-negative model isoprene degrader to study isoprene metabolism.

Supplementary Materials: The following are available online at http://www.mdpi.com/2076-2607/8/3/349/s1, Figure S1: Schematic of an isoprene-fed fermentor; Figure S2: Phylogenetic relationship of Variovorax sp. WS11 to other Variovorax spp.; Figure S3: Putative oxygenase gene clusters in the genome of Variovorax sp. WS11; Figure S4: Expression of isoG induced by isoprene and epoxyisoprene; Figure S5: Expression of $i s o A$ when grown on isoprene, glucose, or a combination of glucose and isoprene; Table S1: Features of the Variovorax sp. WS11 genome; Table S2: Profile of carbon sources capable of sustaining growth of Variovorax sp. WS11; Table S3: Comparison of translated iso genes by BLASTp.

Author Contributions: Conceptualisation, J.C.M., A.T.C. and R.A.D.; Methodology, J.C.M., A.T.C., R.A.D. and N.L.L.-M.; Validation, R.A.D. and M.F.U.H.; Formal Analysis, R.A.D. and N.L.L.-M.; Investigation, R.A.D. and N.L.L.-M.; Resources, R.A.D. and N.L.L.M.; Data Curation, R.A.D.; Writing-Original Draft Preparation, R.A.D.; Writing-Review and Editing, R.A.D., J.C.M., A.T.C. and N.L.L.-M.; Visualisation, R.A.D., A.T.C. and J.C.M.; Supervision, J.C.M. and A.T.C.; Project Administration, J.C.M. and A.T.C.; Funding Acquisition, J.C.M., A.T.C. and N.L.L.-M. All authors have read and agreed to the published version of the manuscript.

Funding: The work on this project was funded through an ERC Advanced Grant to J.C.M. (694578-IsoMet), a Natural Environment Research Council (NERC) grant to J.C.M. (NE/J009725/1), a Leverhulme Trust Early Career Fellowship (ECF-2016-626) to ATC, a Leverhulme Trust grant (RPG-2016-050) to JCM, a Colombian Government Scholarship (No. 646, Colciencias/Newton Fund (2014)) to N.L.L.M and the Earth and Life Systems Alliance (ELSA) at the University of East Anglia.

Conflicts of Interest: The authors declare no conflicts of interest.

\section{References}

1. Guenther, A.B.; Jiang, X.; Heald, C.L.; Sakulyanontvittaya, T.; Duhl, T.; Emmons, L.K.; Wang, X. The Model of Emissions of Gases and Aerosols from Nature Version 2.1 (MEGAN2.1): An Extended and Updated Framework for Modeling Biogenic Emissions. Geosci. Model Dev. 2012, 5, 1471-1492. [CrossRef]

2. Atkinson, R.; Arey, J. Atmospheric Degradation of Volatile Organic Compounds. Chem. Rev. 2003, 103, 4605-4638. [CrossRef] [PubMed]

3. Carlton, A.G.; Wiedinmyer, C.; Kroll, J.H. A Review of Aecondary Organic Aerosol (SOA) Formation from Isoprene. Atmos. Chem. Phys. 2009, 9, 4987-5005. [CrossRef]

4. Fiore, A.M.; Naik, V.; Spracklen, D.V.; Steiner, A.; Unger, N.; Prather, M.; Bergmann, D.; Cameron-Smith, P.J.; Cionni, I.; Collins, W.J.; et al. Global Air Quality and Climate. Chem. Soc. Rev. 2012, 41, 6663-6683. [CrossRef]

5. Trainer, M.; Williams, E.; Parrish, D.; Buhr, M.; Allwine, E.; Westberg, H.; Fehsenfeld, F. Models and Observations of the Impact of Natural Hydrocarbons on Rural Ozone. Nature 1987, 329, 705-707. [CrossRef]

6. Silver, G.M.; Fall, R. Enzymatic Synthesis of Isoprene from Dimethylallyl Diphosphate in Aspen Leaf Extracts. Plant Physiol. 1991, 97, 1588-1591. [CrossRef]

7. Silver, G.M.; Fall, R. Characterization of Aspen Isoprene Synthase, an Enzyme Responsible for Leaf Isoprene Emission to the Atmosphere. J. Biol. Chem. 1995, 22, 13010-13016. [CrossRef]

8. Sharkey, T.D.; Yeh, S. Isoprene Emission from Plants. Annu. Rev. Plant Physiol. Plant Mol. Biol. 2001, 52, 407-436. [CrossRef]

9. Vickers, C.E.; Gershenzon, J.; Lerdau, M.T.; Loreto, F. A Unified Mechanism of Action for Volatile Isoprenoids in Plant Abiotic Stress. Nat. Chem. Biol. 2009, 5, 283-291. [CrossRef]

10. Vickers, C.E.; Possell, M.; Cojocariu, C.I.; Velikova, V.B.; Laothawornkitkul, J.; Ryan, A.; Mullineaux, P.M.; Hewitt, C.N. Isoprene Synthesis Protects Transgenic Tobacco Plants from Oxidative Stress. Plant Cell Environ. 2009, 32, 520-531. [CrossRef] [PubMed] 
11. Zuo, Z.; Weraduwage, S.M.; Lantz, A.T.; Sanchez, L.M.; Weise, S.E. Isoprene Acts as a Signaling Molecule in Gene Networks Important for Stress Responses and Plant Growth. Plant Physiol. 2019, 180, 124-152. [CrossRef] [PubMed]

12. Lantz, A.T.; Allman, J.; Sharkey, T.D. Isoprene: New Insights into the Control of Emission and Mediation of Stress Tolerance by Gene Expression. Plant. Cell Environ. 2019, 42, 2808-2826. [CrossRef] [PubMed]

13. Harvey, C.M.; Sharkey, T.D. Exogenous Isoprene Modulates Gene Expression in Unstressed Arabidopsis thaliana Plants. Plant Cell Environ. 2016, 39, 1251-1263. [CrossRef] [PubMed]

14. Bonsang, B.; Polle, C.; Lambert, G. Evidence for Marine Production of Isoprene. Geophys. Res. Lett. 1992, 19, 1129-1132. [CrossRef]

15. Dani, K.G.S.; Silva, A.M.; Michelozzi, M.; Peluso, G.; Torzillo, G.; Loreto, F. Relationship between Isoprene Emission and Photosynthesis in Diatoms, and Its Implications for Global Marine Isoprene Estimates. Mar. Chem. 2017, 189, 17-24. [CrossRef]

16. Shaw, S.L.; Gantt, B.; Meskhidze, N. Production and Emissions of Marine Isoprene and Monoterpenes: A Review. Adv. Meteorol. 2010, 2010, 1-24. [CrossRef]

17. Alvarez, L.A.; Exton, D.A.; Timmis, K.N.; Suggett, D.J.; McGenity, T.J. Characterization of Marine Isoprene-Degrading Communities. Environ. Microbiol. 2009, 11, 3280-3291. [CrossRef]

18. Cleveland, C.C.; Yavitt, J.B. Microbial Consumption of Atmospheric Isoprene in a Temperate Forest Soil. Appl. Environ. Microbiol. 1998, 64, 172-177. [CrossRef]

19. Cleveland, C.; Yavitt, J. Consumption of Atmospheric Isoprene in Soil. Geophys. Res. Lett. 1997, $24,2379-2382$. [CrossRef]

20. Van Ginkel, C.G.; De Jong, E.; Tilanus, J.W.R.; De Bont, J.A.M. Microbial Oxidation of Isoprene, a Biogenic Foliage Volatile and of 1,3-Butadiene, an Anthropogenic Gas. FEMS Microbiol. Lett. 1987, 45, 275-279. [CrossRef]

21. Ewers, J.; Freier-schriider, D.; Knackmuss, H. Selection of Trichloroethene (TCE) Degrading Bacteria That Resist Inactivation by TCE. Arch. Microbiol. 1990, 154, 410-413. [CrossRef] [PubMed]

22. Van Hylckama Vlieg, J.E.; Kingma, J.; van den Wijngaard, A.J.; Janssen, D.B. A Glutathione S-Transferase with Activity towards Cis-1, 2-Dichloroepoxyethane is Involved in Isoprene Utilization by Rhodococcus sp. Strain AD45. Appl. Environ. Microbiol. 1998, 64, 2800-2805. [CrossRef] [PubMed]

23. Hylckama Vlieg, J.E.; Kingma, J.; Kruizinga, W.; Janssen, D.B. Purification of a Glutathione S-Transferase and a Glutathione Conjugate-Specific Dehydrogenase Involved in Isoprene Metabolism in Rhodococcus sp. Strain AD45. J. Bacteriol. 1999, 181, 2094-2101. [CrossRef] [PubMed]

24. van Hylckama Vlieg, J.E.T.; Leemhuis, H.; Jeffrey, H.; Spelberg, L.; Janssen, D.B. Characterization of the Gene Cluster Involved in Isoprene Metabolism in Characterization of the Gene Cluster Involved in Isoprene Metabolism in Rhodococcus sp. Strain AD45. J. Bacteriol. 2000, 187, 1956-1963. [CrossRef] [PubMed]

25. Allen, J.R.; Ensign, S.A. Carboxylation of Epoxides to $\beta$-Keto Acids in Cell Extracts of Xanthobacter Strain Py2. J. Bacteriol. 1996, 178, 1469-1472. [CrossRef] [PubMed]

26. El Khawand, M.; Crombie, A.T.; Johnston, A.; Vavlline, D.V.; McAuliffe, J.C.; Latone, J.A.; Primak, Y.A.; Lee, S.K.; Whited, G.M.; McGenity, T.J.; et al. Isolation of Isoprene Degrading Bacteria from Soils, Development of isoA Gene Probes and Identification of the Active Isoprene-Degrading Soil Community Using DNA-Stable Isotope Probing. Environ. Microbiol. 2016, 18, 2743-2753. [CrossRef] [PubMed]

27. Carrión, O.; Larke-mejía, N.L.; Gibson, L.; Farhan, M.; Haque, U.; Ramiro-garcía, J.; Mcgenity, T.J.; Murrell, J.C. Gene Probing Reveals the Widespread Distribution, Diversity and Abundance of Isoprene-Degrading Bacteria in the Environment. Microbiome 2018, 6, 1-11. [CrossRef]

28. Crombie, A.T.; Larke-mejia, N.L.; Emery, H.; Dawson, R.; Pratscher, J.; Murphy, G.P. Poplar Phyllosphere Harbors Disparate Isoprene- Degrading Bacteria. Proc. Natl. Acad. Sci. USA 2018, 115, 13081-13086. [CrossRef]

29. Johnston, A.; Crombie, A.T.; El Khawand, M.; Sims, L.; Whited, G.M.; McGenity, T.J.; Colin Murrell, J. Identification and Characterisation of Isoprene-Degrading Bacteria in an Estuarine Environment. Environ. Microbiol. 2017, 19, 3526-3537. [CrossRef]

30. Larke-Mejía, N.L.; Crombie, A.T.; Pratscher, J.; Mcgenity, T.J.; Murrell, J.C. Novel Isoprene-Degrading Proteobacteria from Soil and Leaves Identified by Cultivation and Metagenomics Analysis of Stable Isotope Probing Experiments. Front. Microbiol. 2019, 10, 1-13. [CrossRef] 
31. Singh, A.; Srivastava, N.; Dubey, S.K. Molecular Characterization and Kinetics of Isoprene Degrading Bacteria. Bioresour. Technol. 2019, 278, 51-56. [CrossRef] [PubMed]

32. Srivastva, N.; Singh, A.; Bhardwaj, Y.; Dubey, S.K. Biotechnological Potential for Degradation of Isoprene: A Review. Crit. Rev. Biotechnol. 2017, 1-13. [CrossRef] [PubMed]

33. Willems, A.; De ley, J.; Gillis, M.; Kersters, K. Comamonadaceae, a New Family Encompassing the Acidovorans rRNA Complex, Including Variovorax paradoxus Gen. Nov., Comb. Nov., for Alcaligenes paradoxus (Davis 1969). Int. J. Syst. Bacteriol. 1991, 41, 445-450. [CrossRef]

34. Brandt, U.; Hiessl, S.; Schuldes, J.; Thürmer, A.; Wübbeler, J.H.; Daniel, R.; Steinbüchel, A. Genome-Guided Insights into the Versatile Metabolic Capabilities of the Mercaptosuccinate-Utilizing $\beta$-Proteobacterium Variovorax paradoxus Strain B4. Environ. Microbiol. 2014, 16, 3370-3386. [CrossRef] [PubMed]

35. Breugelmans, P.; Barken, K.B.; Tolker-nielsen, T.; Hofkens, J.; Dejonghe, W.; Springael, D. Architecture and Spatial Organization in a Triple-Species Bacterial Biofilm Synergistically Degrading the Phenylurea Herbicide Linuron. FEMS Microbiol. Ecol. 2008, 64, 271-282. [CrossRef]

36. Han, J.; Choi, H.; Lee, S.; Orwin, P.M.; Kim, J.; Laroe, S.L.; Kim, T.; Neil, J.O.; Leadbetter, J.R.; Lee, S.Y.; et al. Complete Genome Sequence of the Metabolically Versatile Plant Growth-Promoting Endophyte Variovorax paradoxus S110. J. Bacteriol. 2011, 193, 1183-1190. [CrossRef]

37. Woo, H.L.; Hazen, T.C.; Simmons, B.A.; Deangelis, K.M. Enzyme Activities of Aerobic Lignocellulolytic Bacteria Isolated from Wet Tropical Forest Soils. Syst. Appl. Microbiol. 2014, 37, 60-67. [CrossRef]

38. Lee, J.; Lee, C.S.; Hugunin, K.M.; Maute, C.J.; Dysko, R.C. Bacteria from Drinking Water Supply and Their Fate in Gastrointestinal Tracts of Germ-Free Mice: A Phylogenetic Comparison Study. Water Res. 2010, 44, 5050-5058. [CrossRef]

39. Suyama, T.; Hosoya, H.; Tokiwa, Y. Bacterial Isolates Degrading Aliphatic Polycarbonates. FEMS Microbiol. Lett. 1998, 161, 255-261. [CrossRef]

40. Futamata, H.; Harayama, S.; Watanabe, K. Group-Specific Monitoring of Phenol Hydroxylase Genes for a Functional Assessment of Phenol-Stimulated Trichloroethylene Bioremediation. Appl. Environ. Microbiol. 2001, 67, 4671-4677. [CrossRef]

41. Futamata, H.; Nagano, Y.; Watanabe, K.; Hiraishi, A. Unique Kinetic Properties of Phenol-Degrading Variovorax Strains Responsible for Efficient Trichloroethylene Degradation in a Chemostat Enrichment Culture. Appl. Environ. Microbiol. 2005, 71, 904-911. [CrossRef] [PubMed]

42. Satola, B.; Wübbeler, J.H.; Steinbüchel, A. Metabolic Characteristics of the Species Variovorax paradoxus. Appl. Microbiol. Biotechnol. 2013, 97, 541-560. [CrossRef] [PubMed]

43. Dorn, E.; Hellwig, I.V.; Reineke, W.; Knackmuss, H.-J. Isolation and Characterization of a 3-Chlorobenzoate Degrading Pseudomonad. Arch. Microbiol. 1974, 99, 61-70. [CrossRef] [PubMed]

44. Kanagawa, T.; Dazai, M.; Fukuoka, S. Degradation of O,O-Dimethyl Phosphorodithioate by Thiobacillus thioparus TK-1 and Pseudomonas. Agric. Biol. Chem. 1982, 46, 2571-2578.

45. Crombie, A.T.; Khawand, M.E.; Rhodius, V.A.; Fengler, K.A.; Miller, M.C.; Whited, G.M.; McGenity, T.J.; Murrell, J.C. Regulation of Plasmid-Encoded Isoprene Metabolism in Rhodococcus, a Representative of an Important Link in the Global Isoprene Cycle. Environ. Microbiol. 2015, 17, 3314-3329. [CrossRef]

46. Vallenet, D.; Calteau, A.; Dubois, M.; Amours, P.; Bazin, A.; Burlot, L.; Bussell, X.; Gautreau, G.; Langlois, J.; Roche, D.; et al. MicroScope: An Integrated Platform for the Annotation and Exploration of Microbial Gene Functions through Genomic, Pangenomic and Metabolic Comparative Analysis. Nucleic Acids Res. 2019, 1, 1-11. [CrossRef]

47. Altschul, S.; Gish, W.; Miller, W.; Myers, E.; Lipman, D. Basic Local Alignment Search Tool. J. Mol. Biol. 1990, 215, 403-410. [CrossRef]

48. Carver, T.; Harris, S.R.; Berriman, M.; Parkhill, J.; Mcquillan, J.A. Artemis: An Integrated Platform for Visualization and Analysis of High-Throughput Sequence-Based Experimental Data. Bioinformatics 2012, 28, 464-469. [CrossRef]

49. Schäfer, A.; Tauch, A.; Jsger, W.; Kalinowski, J.; Thierbachb, G.; Piihler, A. Small Mobilizable Multi-Purpose Cloning Vectors Derived from the Escherichia coli Plasmids pK18 and pK19: Selection of Defined Deletions in the Chromosome of Corynebacterium glutamicum. Gene 1994, 145, 69-73. [CrossRef]

50. Dennis, J.J.; Zylstra, G.J. Plasposons: Modular Self-Cloning Minitransposon Derivatives for Rapid Genetic Analysis of Gram-Negative Bacterial Genomes. Appl. Environ. Microbiol. 1998, 64, 2710-2715. [CrossRef] 
51. Pehl, M.; Jamieson, W.D.; Kong, K.; Forbester, J.; Fredendall, R.; Gregory, G.; Mcfarland, J.; Healy, J.; Orwin, P. Genes That Influence Swarming Motility and Biofilm Formation in Variovorax paradoxus EPS. PLoS ONE 2012, 7, e31832. [CrossRef] [PubMed]

52. Kovach, M.E.; Elzer, P.H.; Hill, D.S.; Robertson, G.T.; Farris, M.A.; Roop, R.M.; Peterson, K.M. Four New Derivatives of the Broad-Host-Range Cloning Vector PBBR1MCS, Carrying Different Antibiotic-Resistance Cassettes. Gene 1995, 166, 175-176. [CrossRef]

53. Gilbert, B.; McDonald, I.R.; Finch, R.; Stafford, G.P.; Nielsen, A.K.; Murrell, J.C. Molecular Analysis of the Pmo (Particulate Methane Monooxygenase) Operons from Two Type II Methanotrophs. Appl. Environ. Microbiol. 2000, 66, 966-975. [CrossRef] [PubMed]

54. Schmittgen, T.D.; Livak, K.J. Analyzing Real-Time PCR Data by the Comparative CT Method. Nat. Protoc. 2008, 3, 1101-1108. [CrossRef] [PubMed]

55. Clark, L.; Wolf, R.; Granger, D.; Taylor, Z. Continuous Recording of Blood Oxygen Tensions by Polarography. J. Appl. Physiol. 1953, 6, 189-193. [CrossRef] [PubMed]

56. Green, M.J.; Hill, H.A.O. Chemistry of Dioxygen. Methods Enzymol. 1984, 105, 3-22.

57. Sander, R. Compilation of Henry's Law Constants (Version 4.0) for Water as Solvent. Atmos. Chem. Phys. 2015, 15, 4399-4981. [CrossRef]

58. Nielsen, A.K.; Gerdes, K.; Degn, H.; Murrel, J.C. Regulation of Bacterial Methane Oxidation: Transcription of the Soluble Methane Mono-Oxygenase Operon of Methylococcus capsulatus (Bath) Is Repressed by Copper Ions. Microbiology 1996, 142, 1289-1296. [CrossRef]

59. Brusseau, G.A.; Tsien, H.; Hanson, R.S.; Wackett, L.P. Optimization of Trichloroethylene Oxidation by Methanotrophs and the Use of a Colorimetric Assay to Detect Soluble Methane Monooxygenase Activity. Biodegradation 1990, 1, 19-29. [CrossRef]

60. Colby, B.J.; Stirling, D.I.; Dalton, H. The Soluble Methane Mono-Oxygenase of Methylococcus capsulatus (Bath). Biochem. J. 1977, 165, 395-402. [CrossRef]

61. Nakashima, N.; Tamura, T. Isolation and Characterization of a Rolling-Circle-Type Plasmid from Rhodococcus erythropolis and Application of the Plasmid to Multiple-Recombinant-Protein Expression. Appl. Environ. Microbiol. 2004, 70, 5557-5568. [CrossRef] [PubMed]

62. Zhang, Z.; Schwartz, S.; Wagner, L.; Miller, W. A Greedy Algorithm for Aligning DNA Sequences. J. Comput. Biol. 2000, 7, 203-214. [CrossRef] [PubMed]

63. Satsuma, K. Mineralisation of the Herbicide Linuron by Variovorax sp. Strain RA8 Isolated from Japanese River Sediment Using an Ecosystem Model (Microcosm). Pest Manag. Sci. 2010, 66, 847-852. [PubMed]

64. Aziz, R.K.; Bartels, D.; Best, A.A.; Dejongh, M.; Disz, T.; Edwards, R.A.; Formsma, K.; Gerdes, S.; Glass, E.M.; Kubal, M.; et al. The RAST Server: Rapid Annotations Using Subsystems Technology. BMC Genomics 2008, 9 , 1-15. [CrossRef]

65. Overbeek, R.; Olson, R.; Pusch, G.D.; Olsen, G.J.; Davis, J.J.; Disz, T.; Edwards, R.A.; Gerdes, S.; Parrello, B.; Shukla, M.; et al. The SEED and the Rapid Annotation of Microbial Genomes Using Subsystems Technology (RAST). Nucleic Acids Res. 2014, 42, 206-214. [CrossRef]

66. Brettin, T.; Davis, J.J.; Disz, T.; Edwards, R.A.; Gerdes, S.; Olsen, G.J.; Olson, R.; Overbeek, R.; Parrello, B.; Pusch, G.D.; et al. RASTtk: A Modular and Extensible Implementation of the RAST Algorithm for Annotating Batches of Genomes. Sci. Rep. 2015, 5, 1-6. [CrossRef]

67. De Marco, P.; Moradas-ferreira, P.; Higgins, T.P.; Donald, I.A.N.M.C.; Kenna, E.M.; Murrell, J.C. Molecular Analysis of a Novel Methanesulfonic Acid Monooxygenase from the Methylotroph Methylosulfonomonas methylovora. J. Bacteriol. 1999, 181, 2244-2251. [CrossRef]

68. Jamshad, M.; Marco, P.D.; Pacheco, C.C.; Hanczar, T.; Murrell, J.C. Identification, Mutagenesis, and Transcriptional Analysis of the Methanesulfonate Transport Operon of Methylosulfonomonas methylovora. Appl. Environ. Microbiol. 2006, 72, 276-283. [CrossRef]

69. Eichhorn, E.; Van Der Ploeg, J.R.; Kertesz, M.A.; Leisinger, T. Characterization of $\alpha$-Ketoglutarate-Dependent Taurine Dioxygenase from Escherichia coli. J. Biol. Chem. 1997, 272, 23031-23036. [CrossRef]

70. Zhou, N.; Fuenmayor, S.L.; Williams, P.A. Nag Genes of Ralstonia (Formerly Pseudomonas) sp. Strain U2 Encoding Enzymes for Gentisate Catabolism. J. Bacteriol. 2001, 183, 700-708. [CrossRef]

71. Izmalkova, T.Y.; Sazonova, O.; Nagornih, M.; Sokolov, S.L.; Kosheleva, I.A.; Boronin, A. The Organization of Naphthalene Degradation Genes in Pseudomonas putida. Res. Microbiol. 2013, 164, 244-253. [CrossRef] [PubMed] 
72. Lienkamp, A.; Heine, T.; Tischler, D. Glutathione: A Powerful but Rate Cofactor among Actinobacteria. Adv. Appl. Microbiol. 2020, in press.

73. Heine, T.; Zimmerling, J.; Ballmann, A.; Kleeberg, S.B.; Rückert, C.; Busche, T.; Winkler, A.; Kalinowski, J.; Poetsch, A.; Scholtissek, A.; et al. On the Enigma of Glutathione-Dependent Styrene Degradation in Gordonia rubripertincta CWB2. Appl. Environ. Microbiol. 2018, 84, 1-16. [CrossRef] [PubMed]

74. Johnson, T.; Newton, G.L.; Fahey, R.C.; Rawat, M. Unusual Production of Glutathione in Actinobacteria. Arch. Microbiol. 2009, 191, 89-93. [CrossRef] [PubMed]

75. Moonen, J.H.; Kamerbeek, N.M.; Westphal, A.H.; Boeren, S.A.; Janssen, D.B.; Fraaije, M.W.; van Berkel, W.J.H. Elucidation of the 4-Hydroxyacetophenone Catabolic Pathway in Pseudomonas fluorescens ACB. J. Bacteriol. 2008, 190, 5190-5198. [CrossRef]

76. Maceachran, D.P.; Sinskey, A.J. The Rhodococcus opacus TadD Protein Mediates Triacylglycerol Metabolism by Regulating Intracellular NAD(P)H Pools. Microb. Cell Fact. 2013, 12, 1-12. [CrossRef]

77. Kumar, S.; Stecher, G.; Tamura, K. MEGA7: Molecular Evolutionary Genetics Analysis Version 7.0 for Bigger Datasets. Mol. Biol. Evoution 2016, 33, 1870-1874. [CrossRef]

78. Dalton, H.; Whittenbury, R. The Acetylene Reduction Technique as an Assay for Nitrogenase Activity in the Methane Oxidizing Bacterium Methylococcus capsulatus Strain Bath. Arch. Microbiol. 1976, 109, 147-151. [CrossRef]

79. Prior, S.D.; Dalton, H. Acetylene as a Suicide Substrate and Active Site Probe for Methane Monooxygenase from Methylococcus capsulatus (Bath). FEMS Microbiol. Lett. 1985, 29, 105-109. [CrossRef]

80. Crombie, A.T. Metabolism of Methane and Propane and the Role of the Glyoxylate Bypass Enzymes in Methylocella Silvestris BL2. Ph.D. Thesis, University of Warwick, Coventry, UK, 2011.

(C) 2020 by the authors. Licensee MDPI, Basel, Switzerland. This article is an open access article distributed under the terms and conditions of the Creative Commons Attribution (CC BY) license (http://creativecommons.org/licenses/by/4.0/). 